\title{
Obtaining and Characterizing 3D Printable Polymer Based Composites with $\mathrm{BaTiO}_{3}$ Filler
}

\author{
ALINA RUXANDRA CARAMITU ${ }^{1}$, RADU DASCALU ${ }^{1}$, IOANA ION ${ }^{1}$, VIOLETA TSAKIRIS ${ }^{1}$, \\ NICOLAE STANCU ${ }^{1}$, MIHAELA ARADOAEI ${ }^{2}$, ROMEO CRISTIAN CIOBANU ${ }^{3}$, \\ ADRIANA MARIANA BORS ${ }^{4 *}$, IOSIF LINGVAY ${ }^{5}$ \\ ${ }^{1}$ National Institute for Research and Development in Electrical Engineering INCDIE ICPE-CA, 313 Splaiul Unirii, 030138, Bucharest, \\ Romania \\ ${ }^{2}$ ALL GREEN SRL, 8 George Cosbuc Str., 700470, Iasi, Romania \\ ${ }^{3}$ Gheorghe Asachi Technical University of Iasi, Faculty of Electrical Engineering, 65 Profesor Dimitrie Mangeron Blvd., Iasi, 700259, \\ Romania \\ ${ }^{4}$ ICPE SA, 313 Splaiul Unirii, 030138, Bucharest, Romania \\ ${ }^{5}$ Research-Development Institute for Environmental Protection Technologies and Equipment, 7 Parcului Str., 420035, Bistrita, Romania
}

\begin{abstract}
By the extrusion and injection technique, polymer-based composite samples (polypropylene and thermoplastic polyurethane) were obtained with $\mathrm{BaTiO}_{3}$ filler in concentrations between $\mathrm{O}$ and 35 $\%$. Following the preliminary characterizations performed by coupled thermal analysis techniques, it was found that the composite samples obtained have thermal stability up to a temperature of about 250 ${ }^{\circ} \mathrm{C}$ and can be processed by extrusion at temperatures between 180 and $240^{\circ} \mathrm{C}$. Above this temperature, a series of degradation processes take place by successive thermooxidation with the formation of volatile products.The electrical characterization of the composite samples was performed by the dielectric spectroscopy technique, which showed that the $\Delta t g \delta$ dielectric losses increase as the $\mathrm{BaTiO}_{3}$ content of the composite increases. The maximum increase being recorded at $50 \mathrm{~Hz}$ (the slope $\Delta$ tg $\delta 1 \% \mathrm{BaTiO}_{3}$ about $0.0031 \% \mathrm{BaTiO}_{3}$ ). It was also found, that the electrical conductivity $(\sigma)$ of the composite increases with the increase of content in $\mathrm{BaTiO}_{3}$ so that $\sigma$ at $100 \mathrm{kHz}$ for the composite with $35 \% \mathrm{BaTiO}_{3}$ is about 50 times higher than for the reference sample $M 0$ (without filler).
\end{abstract}

Keywords: composite, thermoplastic polyurethane, polypropylene, $\mathrm{BaTiO}_{3}$, dielectric loss, conductivity

\section{Introduction}

The In the perspective of sustainable development, the rational use of natural resources, respectively, the development of environmentally friendly advanced materials and technologies is a priority issue [1, 2]. In this context, the development of the composite materials with specific characteristics for the most diverse applications is in the continuous attention of the scientific community and industrial developers [3]. Thus, developments of ceramic composites [4] for various medical applications [5, 6], electrodes for electrochemical synthesis [7], thin layers for photocatalysis [8], polymer-based composites with various fillers [9 - 16] are reported with uses including the electrical engineering field [17-20], etc.

The composite materials development is intended to meet the specific requirements of the target application such as biocompatibility [5, 6], flammability [21], electrical, dielectric, and/or magnetic performance [17-20], ablation [9], mechanical characteristics [14, 20], resistance to the action of microorganisms/biodegradability $[11,22,23]$, etc. The development of 3D printers has opened new research directions in the field of advanced materials, respectively the performed of 3D printable materials. In this context, the purpose of the work is the realization and preliminary characterization of composites based on the thermoplastic polymer with filler $\mathrm{BaTiO}_{3}$ for $3 \mathrm{D}$ printing applications.

\section{Materials and methods}

By the technique of extrusion and injection, composite samples based on thermoplastic polyurethane and polypropylene with $\mathrm{BaTiO}_{3}$ filler were obtained.

\footnotetext{
*email: adrianambors@gmail.com
} 
After weighing, the components (polyurethane and polypropylene pellets with $\mathrm{BaTiO}_{3}$ powder) were mixed (for $30 \mathrm{~min}$ at speed $40 \mathrm{rpm}$ ) in a TURBULA T2F type cylindrical mixer.

The main characteristics of the polypropylene used (TIPPLEN H 318) [24] are shown in Table 1.

Table 1. Characteristics of TIPPLEN H 318 polypropylene [24]

\begin{tabular}{|c|c|c|c|}
\hline Properties & Thest method & Unit & Typical value \\
\hline MFR $\left(230^{\circ} / 2.16 \mathrm{KG}\right)$ & ISO 1133 & $\mathrm{~g} / 10 \mathrm{~min}$. & 12 \\
\hline Tensile strength at yield & ISO $527-1,2$ & $\mathrm{MPa}$ & 29 \\
\hline Tensile elongation at yield & ISO $527-1,2$ & $\%$ & 12 \\
\hline Modulus of elasticity tension & ISO $527-1,2$ & $\mathrm{MPa}$ & 1050 \\
\hline Flexural modulus & ISO 178 & $\mathrm{MPa}$ & 1000 \\
\hline Izod impact strengts $\left(\right.$ notched $\left.23^{\circ} \mathrm{C}\right)$ & ISO $180 / 1 \mathrm{~A}$ & $\mathrm{~kJ} / \mathrm{m}^{2}$ & 6 \\
\hline HDT $\left(0.46 \mathrm{~N} / \mathrm{mm}^{2}\right)$ & ISO $75-1,2$ & ${ }^{\circ} \mathrm{C}$ & 87 \\
\hline Rockwell hardness & ISO $2039 / 2$ & $\mathrm{R} \mathrm{scale}$ & 82 \\
\hline
\end{tabular}

The main characteristics of the polyurethane used (Estane 58887 TPU supplied by Lubrizol Advanced Materials, Inc. [25]) are shown in Table 2.

Table 2. Thermoplastic polyurethane characteristics used [25]

\begin{tabular}{|c|c|c|c|}
\hline Properties & Value & Unit & Test method \\
\hline Hardness $(5 \mathrm{sec})$ & $87+/-3$ & Shore A & ASTM D-2240 \\
\hline Specific gravity & 1.12 & & ASTM D-792 \\
\hline Tensile strength & 7500 & $\mathrm{psi}(\mathrm{MPa})$ & ASTM D-412 \\
\hline Ultimate Elongation & 500 & $\%$ & \\
\hline Tensile strength at & & & ASTM D-412 \\
\hline$-100 \%$ Elongation & 1000 & $\mathrm{psi}(\mathrm{MPa})$ & \\
\hline$-300 \%$ Elongation & 1800 & $\mathrm{psi}(\mathrm{MPa})$ & \\
\hline
\end{tabular}

The $\mathrm{BaTiO}_{3}$ powder $(<2 \mu \mathrm{m}, 99.5 \%$ trace metals basis) used was supplied by MERCK.

The composite was obtained by extruding and granulating the polyurethane/polypropylene/ $/ \mathrm{BaTiO}_{3}$ mixture on a KETSE Brabender laboratory extruder.

The size of the composite granules obtained was about $3 \mathrm{~mm}$.

The working parameters on the extruder were:

- rotation speed (counter-rotation) of the extruder screws $95 \mathrm{rpm}$;

- feed speed from the feed hopper $450 \mathrm{rpm}$.

The temperatures on the heating areas of the Brabender KETSE extruder are in Table 3.

Table 3. Temperatures on the heating areas of the extruder

\begin{tabular}{|c|c|c|c|c|c|c|}
\hline Area & 1 & 2 & 3 & 4 & 5 & 6 \\
\hline Temperature $\left[{ }^{\circ} \mathrm{C}\right]$ & 180 & 190 & 200 & 21 & 23 & 220 \\
\hline
\end{tabular}

For the dielectric characterization of the composite, the granules obtained by extrusion were injected (with an injection machine type Dr. Boy A35 - Germany) obtaining samples (specimens) in the form of a disc with a diameter of $30 \mathrm{~mm}$ and a thickness of $2.5 \mathrm{~mm}$.

The working parameters on the injection machine (Boy A35 - Germany) were:

- closing force of the mold in the range: $302-317 \mathrm{kN}$;

- injection pressure 550 bar;

- back pressure: 90 bar.

The temperatures of the heating areas of the injection molding machine were shown in Table 4.

Table 4. Temperatures on the heating areas of the injection molding machine

\begin{tabular}{|c|c|c|c|c|c|}
\hline Area & 5 & 4 & 3 & 2 & 1 \\
\hline Temperature $\left[{ }^{\circ} \mathbf{C}\right]$ & 220 & 210 & 200 & 190 & 180 \\
\hline
\end{tabular}


Thus, samples with different compositions were performed. The sample coding obtained according to the composition is presented in Table 5.

Table 5. Composite samples obtained

\begin{tabular}{|c|c|c|c|}
\hline \multirow{2}{*}{ Sample cod } & \multicolumn{3}{|c|}{ Content [mass \%] } \\
\cline { 2 - 4 } & BaTiO3 powder & PP & TPU \\
\hline M 0 & 0 & 6 & 94 \\
\hline M1 & 12 & 5.1 & 82.9 \\
\hline M2 & 15 & 5 & 80 \\
\hline M3 & 20 & 4.7 & 75.3 \\
\hline M4 & 25 & 4.5 & 70.5 \\
\hline M5 & 28 & 4.3 & 67.7 \\
\hline M6 & 35 & 4 & 61 \\
\hline
\end{tabular}

The thermal characterization of both the polymeric raw materials (polyurethane and polypropylene) and of the composite obtained was performed by thermal analysis techniques on a specialized equipment type STA 449 F3 Jupiter (NETZSCH, Germany). The thermal diagrams were drawn in $50 \mathrm{~mL} / \mathrm{min}$ synthetic air at a heating rate of $10^{\circ} \mathrm{C} / \mathrm{min}$. Dielectric behavior - determination of dielectric loss and conductivity vs. frequency - of the composite samples obtained was investigated at a temperature of 20 $\pm 2^{\circ} \mathrm{C}$ by dielectric spectroscopy technique with 1296 Dielectric interface / AMTEK - Solartron Analytical.

\section{Results and discussions}

The thermal diagrams TG + DSC + DTG recorded on the polyurethane (TPU) used to make the composite are shown in Figure 1.

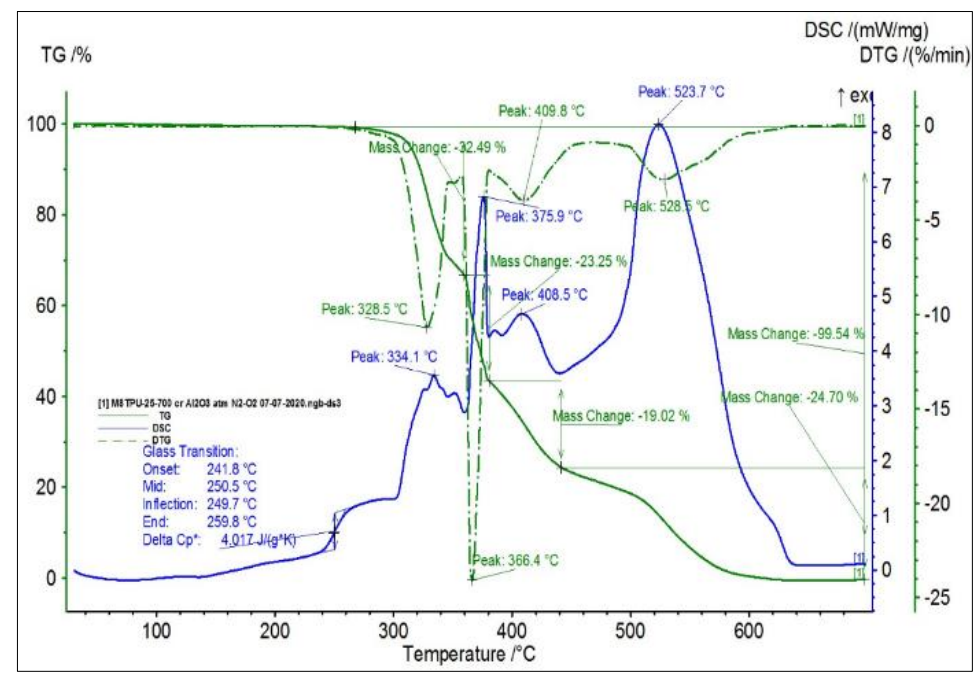

Figure 1. TG + DSC + DTG thermal diagrams recorded on TPU

Analyzing Figure 1, from the DSC curve, it is found that at the progressive heating of TPU, the material undergoes a glass transition that starts at $241.8^{\circ} \mathrm{C}$ and ends at $259.8^{\circ} \mathrm{C}$.

From the comparative analysis of the TG, DSC, and DTG diagrams, it is found that up to the temperature of about $280^{\circ} \mathrm{C}$ the material is stable after which several processes of thermooxidation take place (the first with the formation of solid peroxide products with a peak at $334.1^{\circ} \mathrm{C}$ ) and of decomposition with the formation of volatile products, a process that ends that end at a temperature of about $600^{\circ} \mathrm{C}$ (when the mass loss of the sample is $100 \%$ ).

The thermal diagrams TG + DSC + DTG recorded on polypropylene (PP) used to make the composite are shown in Figure 2. 


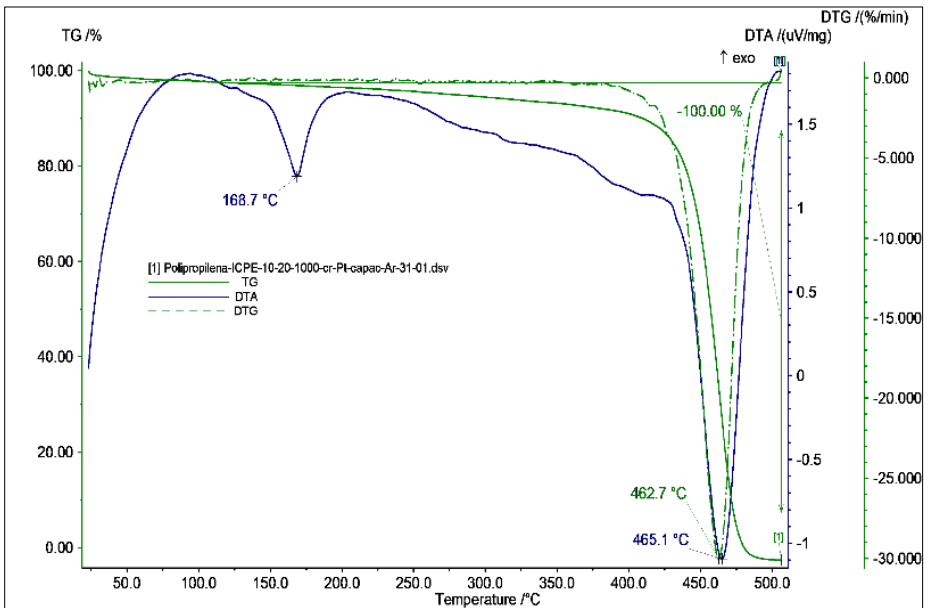

Figure 2. Thermal diagrams TG + DSC + DTG recorded on PP

Analyzing the thermal diagrams in Figure 2 it is found that the PP used for obtaining the composite is a product with an ordered structure with a melting temperature of $168.7^{\circ} \mathrm{C}$ and stable (without processes of thermooxidation and/or decomposition) up to about $425^{\circ} \mathrm{C}$.

At the temperature of $425^{\circ} \mathrm{C}$, a decomposition process begins with the formation of volatile products, a process which ends at $460^{\circ} \mathrm{C}$ when the mass loss of the sample is $100 \%$.

The $\mathrm{BaTiO}_{3}$ component is a particularly stable product at temperatures below $800^{\circ} \mathrm{C}$, as shown in Figure 1 and Figure 2, which indicates that the maximum temperature during processing to obtain the composite is limited by the TPU component and is up to $270^{\circ} \mathrm{C}$.

The thermal TG + DSC + DTG diagrams obtained, recorded on the $M 5$ sample $\left(28 \% \mathrm{BaTiO}_{3}, 4.3 \%\right.$ PP and $67.7 \%$ TPU) are presented in Figure 3.

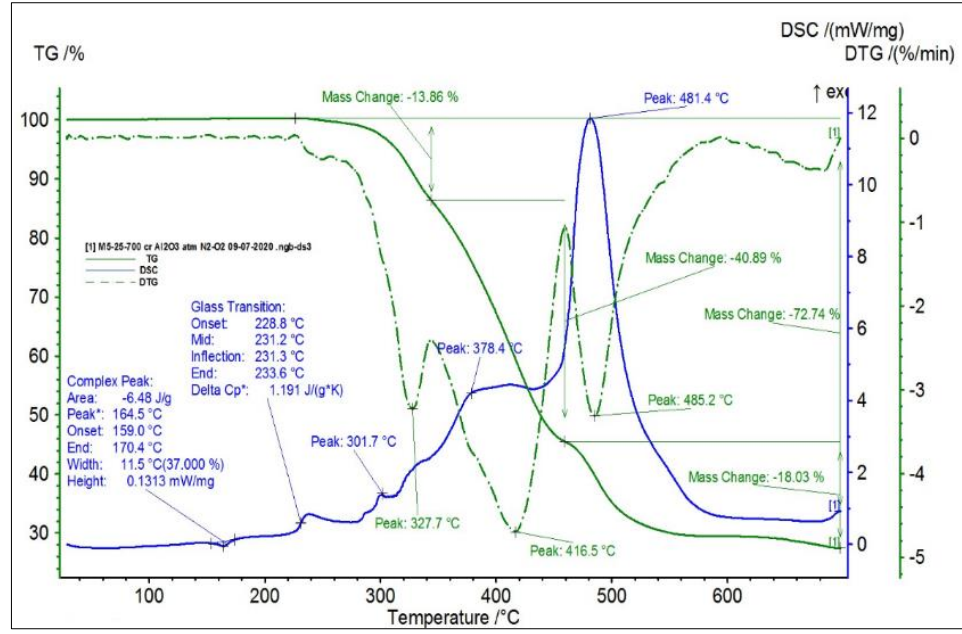

Figure 3. TG + DSC + DTG thermal diagrams recorded on $M 5\left(28 \% \mathrm{BaTiO}_{3}, 4.3 \% \mathrm{PP}\right.$ and $\left.67.7 \% \mathrm{TPU}\right)$

From the analysis of Figure 3 it is found that at the progressive heating of the $M 5$ composite obtained, at about $165^{\circ} \mathrm{C}$ a slightly pronounced melting endotherm process occurs, after which at $228.8^{\circ} \mathrm{C}$ a glass transition process begins, which indicates a biphasic structure respectively, a component with ordered structure (with crystallinity, with definite melting point) and a component with disordered structure (glass transition). The composite is stable up to about $250^{\circ} \mathrm{C}$ when the decomposition begins by the formation of volatile products (in a first stage, up to temperature of $360^{\circ} \mathrm{C}$, the mass loss is $13.86 \%$ ) and successive exothermic thermooxidation processes (first peak at $301.7^{\circ} \mathrm{C}$ ). Decomposition by formation of volatile products is completed at about $550^{\circ} \mathrm{C}$ when the total mass loss is $72.24 \%$, the residue of $27.76 \%$ being 
the weight in the $\mathrm{BaTiO}_{3}$ composite. Based on this experimental data, it is considered that the maximum temperature at which the composite obtained can be processed and / or used is about $240^{\circ} \mathrm{C}$. By comparing the Figure 3 with Figure 1 and Figure 2 it is observed that in the composite are found both the component with the ordered structure of PP (with defined doping point) and the component with the disordered structure of TPU with modified thermal parameters (glass transition at $228.8^{\circ} \mathrm{C}$ instead of $241.8^{\circ} \mathrm{C}$, first peak of thermooxidation occurs at $301.7^{\circ} \mathrm{C}$ instead of $334.1^{\circ} \mathrm{C}$ etc.).

These changes of the thermal parameters of the phase with disordered structure TPU from Figure 3 (compared to Figure 1) suggest that the initial structure of TPU changed following contact with molten PP during applied heat treatments (extrusion and injection). The thermal diagrams recorded on the other composite samples ( $M 1, M 2, M 3, M 4$ and $M 6)$ were practically identical to those recorded on $M 5$, the only differences being recorded at the total mass loss that changes according to the $\mathrm{BaTiO}_{3}$ content of the respective samples. This finding indicates that the polymeric component formed during the composite processing (mixing, extrusion and injection) has a homogeneous structure. By processing the experimental data obtained by dielectric spectroscopy (real and imaginary components of complex permittivity vs. frequency), the dielectric $\operatorname{loss} \operatorname{tg} \delta$ of the investigated material samples was determined.

The values obtained in different frequency ranges are shown in Figure 4.
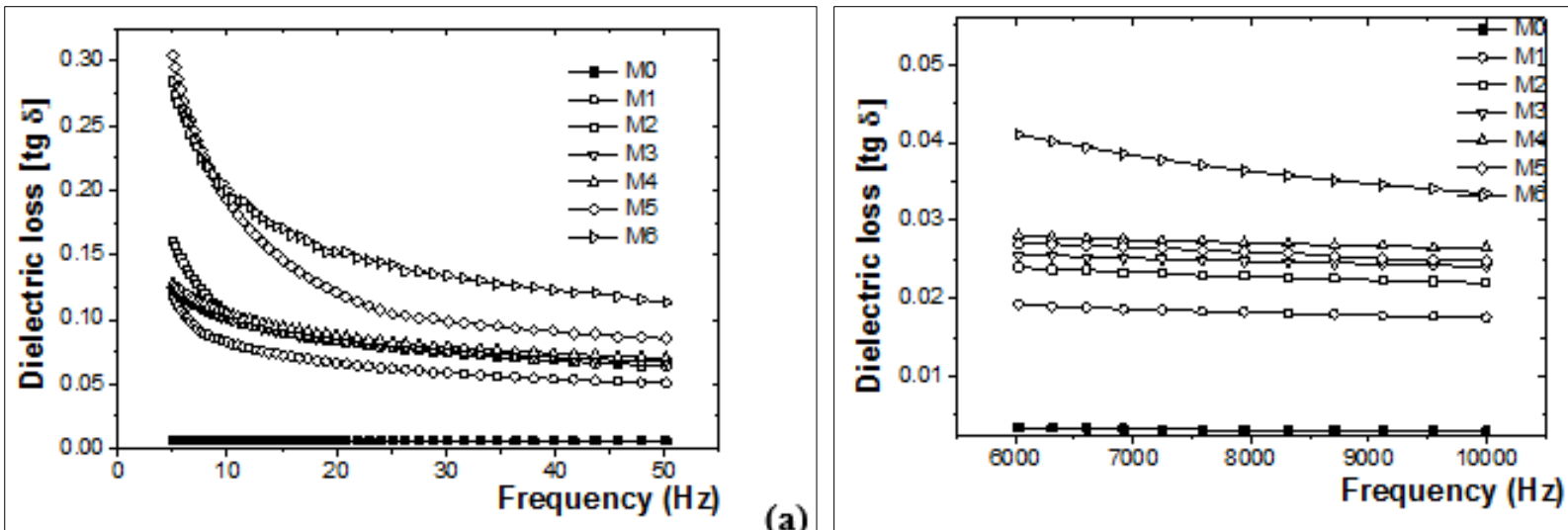

(a)

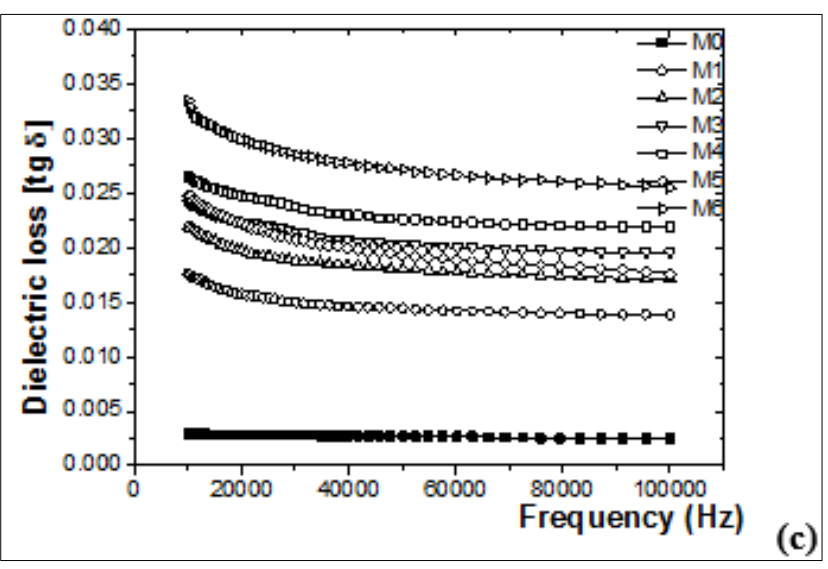

Figure 4. $\operatorname{tg} \delta$ evolution in the frequency ranges:

(a) $5-50 \mathrm{~Hz}$, (b) $6-10 \mathrm{kHz}$ and (c) $10-100 \mathrm{kHz}$

From the analysis of Figure 4 it is found that the dielectric loss value is determined by the content in

$\mathrm{BaTiO}_{3}$ of the composite, respectively increases with increasing the content in $\mathrm{BaTiO}_{3}$. The evolution of dielectric loss depending on the $\mathrm{BaTiO}_{3}$ content of the composite for the several frequencies is shown in Figure 5. 


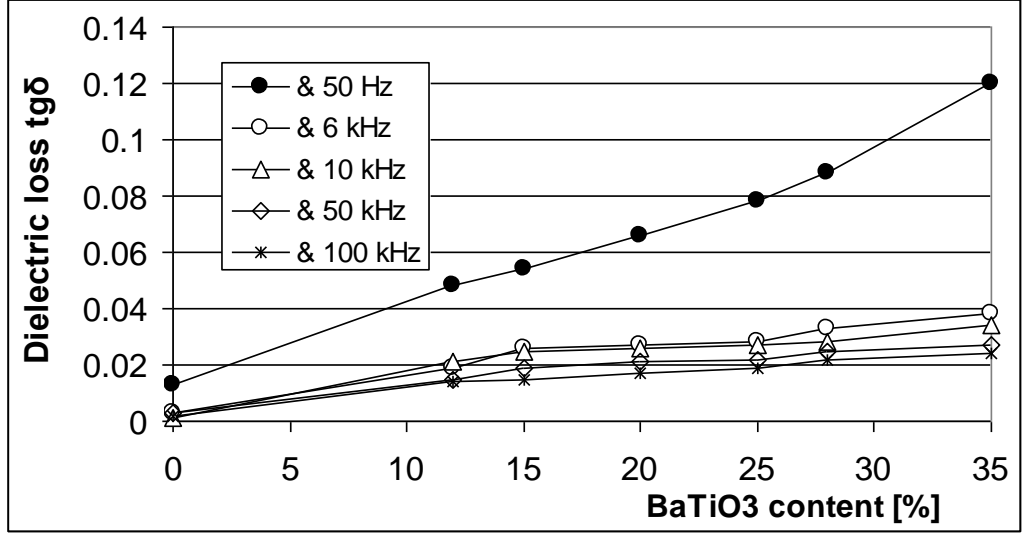

Figure 5. Dielectric loss vs. the $\mathrm{BaTiO}_{3}$ content of the composite

Analysing Figure 5 it is observed that the dielectric evolution of the composite based on PP and TPU polymers with $\mathrm{BaTiO}_{3}$ filler increases approximately linearly as the $\mathrm{BaTiO}_{3}$ content increases, the most pronounced increases being registered at the frequency of $50 \mathrm{~Hz}$ (the slope $\Delta \operatorname{tg} \delta / \% \mathrm{BaTiO}_{3}$ about 0.003 $/ \% \mathrm{BaTiO}_{3}$ ). Evolution of electrical conductivity $\sigma$ depending on the frequency of composite samples in the investigated frequency ranges are shown in Figure 6.

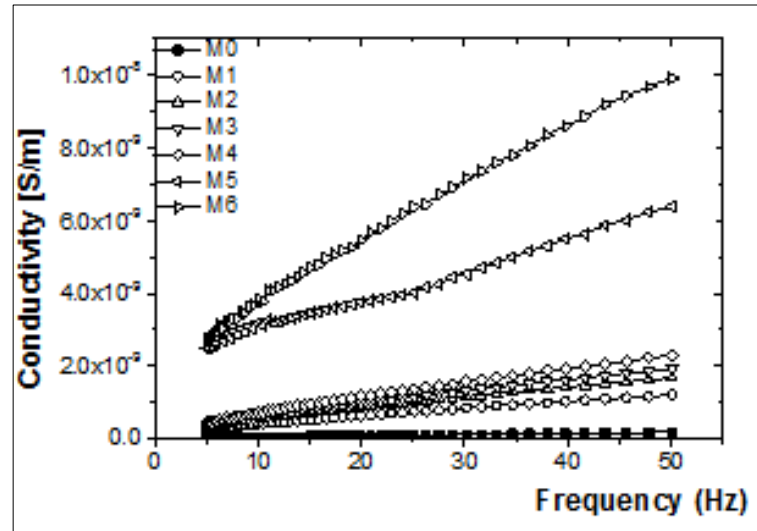

(a)

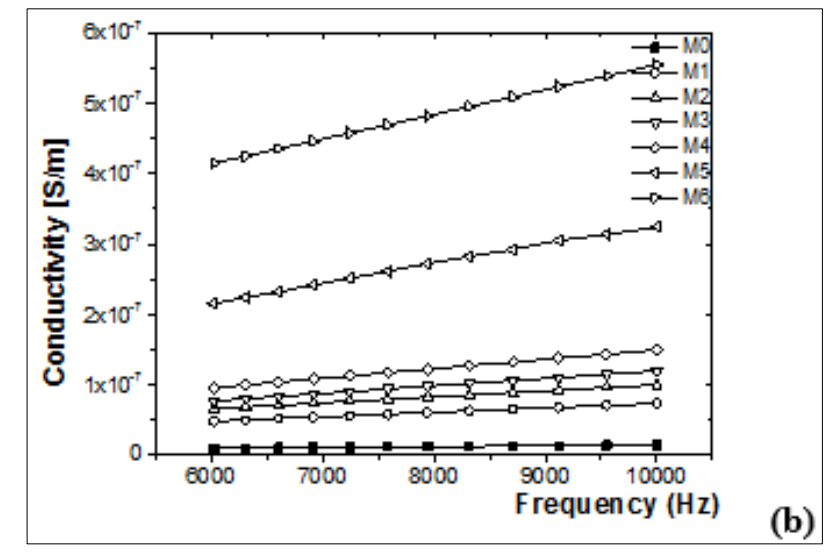

Figure 6. Evolution of electrical conductivity in the frequency ranges (a) $5-50 \mathrm{~Hz}$, (b) $6-10 \mathrm{kHz}$ and (c) $10-100$ $\mathrm{kHz}$ of the analyzed composites

From the analysis of Figure 6 it can be noted that as the $\mathrm{BaTiO}_{3}$ content increases, the electrical conductivity of the composite samples performed increases (for example: up to 50 times at $100 \mathrm{kHz}$ for a $35 \% \mathrm{BaTiO}_{3}$ content).

From these preliminary characterizations, it is found that the composite material based on polymers (polypropylene and thermoplastic polyurethane) with $35 \% \mathrm{BaTiO}_{3}$ filler has adequate electrical and 
thermal characteristics for obtaining wires for 3D printers.

\section{Conclusions}

By the technique of extrusion and injection, samples of polymer-based composite material (polypropylene and thermoplastic polyurethane) with $\mathrm{BaTiO}_{3}$ filler in various concentrations were obtained.

Following the preliminary characterizations performed by coupled techniques of thermal analysis and dielectric spectroscopy of the composite samples obtained, the following were found:

- can be processed by extrusion at temperatures between 180 and $240^{\circ} \mathrm{C}$;

- has a thermal stability up to a temperature of about $250^{\circ} \mathrm{C}$ above which a series of degradation processes begin by successive thermooxidation processes with the formation of volatile products;

- at $600^{\circ} \mathrm{C}$ the decomposition of the polymeric support is complete, the calcination residues consisting only in the $\mathrm{BaTiO}_{3}$ filler from the composite composition;

- $\Delta \operatorname{tg} \delta$ dielectric losses increase with the increasing of $\mathrm{BaTiO}_{3}$ content of the composite, being recorded a maximum increase at $50 \mathrm{~Hz}$ (the slope $\Delta \operatorname{tg} \delta / \% \mathrm{BaTiO}_{3}$ about $0.003 / \% \mathrm{BaTiO}_{3}$ );

- the electrical conductivity $(\sigma)$ of the composite increases as the $\mathrm{BaTiO}_{3}$ content increases, so that the $\sigma$ at $100 \mathrm{kHz}$ of the composite with $35 \% \mathrm{BaTiO}_{3}$ is about 50 times higher than the reference sample M0 (without filler).

Taking in consideration these results, it is found that the composite material based on polymers (polypropylene and thermoplastic polyurethane) with $35 \% \mathrm{BaTiO}_{3}$ filler obtained has adequate electrical and thermal characteristics to obtain the wires for 3D printers.

Acknowledgments: The work was supported by a grant of the Romanian National Authority for Scientific Research and Innovation, CCCDI-UEFISCDI, within PNCDI III program, project ID: COFUND-ERANET MANUNET III - “4DprintEN", contract no. 96/2019, contract PN 19310101/ 2019, and the contract No. 30 PFE/2018 between National R\&D Institute for Electrical Engineering ICPE-CA and Romanian Ministry of Research and Innovation (MCI).

\section{References}

1.STERE, E.A., POPA, I., Environment, modeller of the mankind existence (Part 3), Electrotehnica, Electronica, Automatica (EEA), 65(3), 2017, 213 - 220.

2.STERE, E.A., POPA, I., Regards on the actual stage of the sustainable development, Electrotehnica, Electronica, Automatica (EEA), 66(4), 2018, 127-134.

3.SINHA RAY, S., OKAMOTO, M., Polymer/layered silicate nanocomposites: a review from preparation to processing, Prog. Polym. Sci., 28, 2003, 1539-1641.

4.BURDE, A.V., CUC, S., RADU, A., RUSU, M.A., COSMA, C.S., CÂMPIAN, R.S., LEORDEAN, D., Microstructural Analysis of the Interface between Some Superalloys and Composite/Ceramic Materials, Studia UBB Chemia, LXI (2), 2016, 205-214.

5.BIZO, L., SABO, K., BARÁBAS, R., KATONA, G., BARBU-TUDORAN, L., BERAR, A., Structural, Morphological and Dissolution Properties of ZrO2-Based Biocomposites for Dental Applications, Studia UBB Chemia, LXV (1), 2020, 137-148.

6.BARABÁS, R., RIGÓ, M., ENISZNÉ-BÓDOGH, M., MOISA, C., CADAR, O., Preparation and Characterization of Hydroxyapatite Based Nano-Composite Biomorphic Implants, Studia UBB Chemia, LXIII (3), 2018, 137-154.

7.MACAVEI, S., ŞTEFAN, M., POGACEAN, F., PANĂ, O., LEOSTEAN, C., POPA, A., TOLOMAN, D., BARBU-TUDORAN, L., Synthesis and Characterisation of $\mathrm{Fe}_{3} \mathrm{O}_{4}-\mathrm{SnO}_{2}$ nanocomposites with electrochemical properties, Studia UBB Chemia, LXV (1), 2020, 177-188.

8.TEGZE, B., ALBERT, E., DIKÓ, B., MADARÁSZ, J., SÁFRÁN, G., HÓRVÖLGYI, Z., Thin Layer Photocatalysts of $\mathrm{TiO}_{2}$-Ag Composites, Studia UBB Chemia, LXIV (3), 2019, 81-98. 
9.VAIA, R.A., PRICE, G., RUTH, P.N., NGUYEN, H.T., LICHTENHAN, J., Polymer/layered silicate nanocomposites as high performance ablative materials, Appl. Clay. Sci., 15, 1999, 67-92.

10.BISWAS, M., SINHA, R.S., Recent progress in synthesis and evaluation of polymer-montmorillonite nanocomposites, Adv. Polym. Sci., 155, 2001,167-221.

11.AMMALA, A., BATEMAN, S., DEAN, K., PETINAKIS, E., SANGWAN, P., WONG, S., YUAN, Q., YU, L., PATRICK, C., LEONG, K.H., An overview of degradable and biodegradable polyolefins, Progress in Polymer Science, 36(8), 2011, 1015-1049.

12.BUDASH, Y., NOVAK, D., PLAVAN, V., Structural and Morphological Characteristics of Polyethylene Composites with Different Conductive Fillers, Mater. Plast., 53(4), 2016, 693-697.

13.PROLONGO, S.G., BURÓN, M., GUDE, M.R., CHAOS-MORÁN, R., CAMPO, M., UREÑA, A., Effects of dispersion techniques of carbon nanofibers on the thermo-physical properties of epoxy nanocomposites. Compos. Sci. Technol., 68, 2008, 2722-2730.

14.CIOBANU, R.C., BATRINESCU, G., URSAN, G.A., CARAMITU, A.R., MARINESCU, V., BORS, A.M., LINGVAY, I., Mechanical and Morphostructural Characteristics of Composite Materials Performed by Recycling Mixed Waste of Plastic and Paper, Mater. Plast., 56(3), 2019, 475-478.

15.CARAMITU, A.R., MITREA, S., MARINESCU, V., URSAN, G.A., ARADOAIE, M., LINGVAY, I., Dielectric Behavior and Morphostructural Characteristics of Some HDPE Composites / Metal Nanopowders, Mater. Plast., 56(1), 2019, 103-109.

16.NOVAC, O.C., MARIES, G.R.E., CHIRA, D., NOVAC, M., Studying the Influence of Temperatures, Used for Processing ABS, PA 6.6 and POM, on Certain Electrical Properties, when Injection Moulding Items for the Automotive Industry, by Methods Employed for Determining Relative Permittivity and the Dielectric Dissipation Factor, Mater. Plast. 54(2), 2017, 274-280.

17.NOTINGHER, P. V., STANCU, C., ENESCU, E., Electrical Conductivity of Wood-polymer Composites, Mater. Plast., 48(2), 2011, 171-175.

18.SAVA, M., Thermal and Dielectric Properties of Bismaleimide Polymers, Mater. Plast., 53(3), 2016, 473-477.

19.HAMCIUC, C., HAMCIUC, E., BACOSCA, I., OLARIU, M., Thermal and Electrical Properties of some Poly(ether-imide) Thin Films, Mater. Plast., 47(1), 2010, 11-15.

20.KUŠNEROVÁ, M., VALÍĖEK, M., HARNIĖÁROVÁ, J., HALUZÍKOVÁ, M., ŠKUBALA B.P., Physico-mechanical Properties and Electrical Conductivity of Conductive Plastic Materials, Mater. Plast., 51(2), 2014, 150-152.

21.GILMAN, J.W., JACKSON, C.L., MORGAN, A.B., HARRIS, JR. R., MANIAS, E., GIANNELIS, E.P., WUTHENOW, M., HILTON, D., PHILLIPS, S.H., Flammability properties of polymer-layered silicate nanocomposites, Propylene and polystyrene nanocomposites, Chem. Mater., 12, 2000, 18661873.

22.RUS, T., RADU, E., LINGVAY, I., LINGVAY, M., CIOBOTEA-BARBU, O.C., CAMPUREANU, C., BENGA, F.M., LAZAR, G.C., VAIREANU, D.V., Resistance to the action of filamentous fungi upon some coatings materials, U.P.B. Sci. Bull., Series B, 79(4), 2017, 167-180.

23.CARAMITU, A., BUTOI, N., RUS, T., LUCHIAN, A.M., MITREA, S., The resistance to the action of molds of some painting materials aged by thermal cycling and exposed to an electrical field of $50 \mathrm{~Hz}$, Mater. Plast., 54(2), 2017, 331-337.

24.*** https://www.benerecycling.pl/files/tipplen\%20h\%20318.pdf

25.*** https://plastics.ulprospector.com/datasheet/e87070/estane-58887-tpu

Manuscript received: 30.09 .2020 